Marwah: Jurnal Perempuan, Agama dan Jender

(p-ISSN: 1412-6095 | e-ISSN: 2407-1587)

Vol. 16, No. 1, 2017, Hal. $76-83$

\title{
AKTIFITAS KELOMPOK SERBIS DI KOTA PADANG
}

\author{
ERPIDAWATI \\ Universitas Muhamadiyah, Padang, Indonesia \\ erpidawatis3@yahoo.co.id
}

\begin{abstract}
The purpose of this research is to spread the activities of the serbis group in Padang City. This research uses qualitative method, the subject of research are serbis female Who live in Padang City amounting to 27 people. Data collection techniques use are interview, observation and documentation. Data analysis Techniques is data reduction or data presentatiion. The results of study illustrate that the activities of this group serbis are gathered together in the base camp and carry out activities, sharing together, guiding together and going to cafes for crabbing. The activities they undertake are mostly just for the sake of excitement because their wishes and inspirations can not be fulfilled at home so that these tomboy women carry out activities outside the home and join a group of herbists. The activity of this serbis group on an ordinary day is the same as any other normal person. In general, this group of serbis comes from a broken home family.
\end{abstract}

Keywords: Activity, Women's Group, Serbis

\begin{abstract}
ABSTRAK
Tujuan penelitian ini adalab untuk mengembarkan aktifitas kelompok serbis di Kota Padang. Penelitian ini menggunakan metode kualitatif, subjek penelitian perempuan serbis Kota Padang yang berjumlah sebanyak 27 orang. Teknik, pengumpulan data menggunakan format wawancara, observasi dan dokumentasi. Teknik analisis: reduksi datadisplay data atau penyajian Data. Hasil penelitian mengambarkan bahwa aktivitas kelompok serbis ini adalah berkumpul bersama di basecamp dan melaksanakan kegiatan-kegiatan, bernyayi bersama, bergitar bersama dan pergi ke kafe-kafe untuk clabbing. Aktivitas yang mereka laksanakan kebanyakan hanya untuk mencari kesenangan semata karena keinginan dan inspirasinya tidak dapat terpenubi di rumah sehingga perempuan tomboy ini melaksanakan kegiatan di luar rumah dan bergabung dengan kelompok serbis. Aktivitas kelompok serbis ini pada hari-hari biasa sama dengan orang normal lainnya, Pada umumnya kelompok serbis ini berasal dari keluarga yang brokem home.
\end{abstract}

Kata Kunci : Aktivitas, Kelompok perempuan, Serbis 


\section{A. PENDAHULUAN}

Manusia sejak dilahirkan di dunia ini sudah mempunyai kecenderungan dan atas dasar dorongan nalurinya secara biologis untuk hidup berkelompok. Namun dalam perkembangan selanjutnya manusia hidup tidak hanya sekedar memenuhi kebutuhan biologis belaka, akan tetapi manusia mempunyai kehendak dan kepentingan yang tak terbatas. Atas dasar kehendak dan kepentingan yang tak terbatas itu maka dalam usaha untuk memenuhinya, senantiasa tidak dapat dilakukan sendiri. Sebagaimana ditegaskan Abdulsyani (2007) bahwa manusia sejak dilahirkan di dunia ini sudah mempunyai kecenderungan atas dasar dorongan nalurinya secara biologis untuk hidup berkelompok.

Berdasarkan pernyataan di atas menjadi titik tolak terbentuknya kelompokkelompok sosial yang ada dalam masyarakat pada saat ini. Contoh kelompok sosial yang ada dalam masyarakat yaitu keluarga, kelompok bermain, kelompok belajar, kelompok berdasarkan kesamaan profesi, kelompok berdasarkan kesamaan hobi, instansi pemerintahan, organisasi, sekolah, perguruan tinggi dan lain sebagainya. Banyaknya kelompok tersebut dapat diidentifikasi ke dalam kelompok formal dan informal.

Kelompok formal merupakan organisasi kelompok yang mempunyai peraturan yang tegas dan sengaja dibuat oleh anggotanya untuk ditaati serta untuk mengatur hubungan antar anggotanya., Terdapat struktur organisasi dalam kelompok sehingga ada hierarki di antara anggota kelompok yang menjadi pembatasan tugas dan wewenang. Contohnya instansi pemerintah, partai politik, sekolah dan sebagainya. Sedangkan kelompok informal merupakan organisasi kelompok yang tidak resmi serta tidak mempunyai struktur dan organisasi yang pasti. Jadi, kelompok ini tidak didukung oleh peraturan-peraturan anggaran dasar dan anggaran rumah tangga secara tertulis.

Menarik dari fenomena kelompok informal pada jenis kelamin perempuan di kota Padang adalah kelompok Serbis. Ciri-ciri informal dari kelompok ini adalah serbis merupakan kelompok bermain yang sifatnya tidak resmi, yang ada atas dasar kepentingan dan pengalaman masing-masing anggota yang relatif sama. (Bagong Suyanto, 2007). Serbis adalah kelompok sosial yang ada dalam masyarakat yang berkumpul bersama berdasarkan keinginan yang sama, kesamaan hobi dan pengalaman yang sama yang membentuk sebuah kelompok sosial yang ada dalam masyakat di Kota Padang. Kelompok sosial ini terdiri dari perempuan tomboy yang mengekspresikan dirinya dalam satu kelompok di Kota Padang. Serbis adalah singkatan dari serba bisa, yang diartikan sebagai cewek serba bisa. 
Anggotanya adalah perempuan yang sering disebut dengan tomboy. Kata tomboy identik dengan perempuan yang sikap dan penampilannya seperti laki-laki, mulai dari dandanan, gaya berpakain, rambut, hobi serta tingkah lakunya. Munculnya kelompok serbis di Kota Padang berawal dari adanya kesamaan prilaku, gaya hidup yang sama dan berbeda dengan orang lain, dan kondisi psikologis yang berbeda tersebut membuat mereka menjadi bahan olok-an orang banyak, dan teman sepermainan, sehingga muncul suatu ketidaktentraman dalam pergaulan, sehingga mereka membuat kelompok tersendiri dalam keragaman hidup bersama dalam masyarakat, bergaul sesama orangorang yang sama dan cocok dengan mereka yang akhirnya membentuk suatu kelompok. Kelompok serbis tidak memandang adanya perbedaan, baik status sosial, profesi atau latar belakang keluarga, ada yang berasal dari keluarga berada, pengangguran, pedagang, sopir angkot, sopir pribadi, mahasiswa serta pelajar, yang pada umumnya berasal dari keluarga broken bome. Kedekatan yang terjalin antara sesama anggota menjadikan kelompok mereka sebagai keluarga kedua tempat menyalurkan hobi dan inspirasi mereka.

Beberapa penelitian mengenai perempuan tomboy antara lain yang telah dilakukan oleh Susanti (2005) tentang Psikologis Cewek Tomboy di Kota Padang yang membahas tentang penyebab munculnya sikap tomboy dipengaruhi oleh cara didik anak dari usia dini. Ternyata dandanan atau cara berpakaian anak perempuan yang tomboy, telah terbiasa dari usia dini. Penelitian Syafriati Putri (2003) dengan judul Perspektif Cewek Tomboy dalam Kehidupan Masyarakat di kota Padang, menemukan didikan orang tua menyebabkan muncul sikap tomboy pada anak yang akan menjadi suatu sikap dasar anak dan mempunyai perspektif tersendiri dalam kehidupan masyarakat.

Walaupun banyak penelitian yang dilakukan sebelumnya yang berhubungan dengan perempuan tomboy, namun tulisan ini lebih difokuskan pada fenomena yang terjadi pada kelompok serbis yang ada di kota Padang. Pertanyaan yang ingin dijawab dalam penelitian ini adalah bagaimana aktifitas kelompok serbis (cewek tomboy) di kota Padang. Tujuan penelitian ini adalah untuk mendeskripsikan aktifitas kelompok serbis di Kota Padang, sehingga diperoleh gambaran tentang kelompok informal ini sebagai bahan kajian tentang perempuan tomboy di kota Padang. 


\section{B. TINJAUAN PUSTAKA}

Menurut Bagong Suyanto (2007) biasanya kelompok ini dibentuk atas dasar pengalaman-pengalaman dan kepentingan-kepentingan yang sama dari para anggota. Adapun dalam kelompok informal terdapat klik (qliques), yaitu kelompok yang terikat kuat atas dasar persahabatan atau kepentingan bersama dan mempunyai perasaan kelompok yang sangat kuat.

Menurut Ritzer\& Goodman (2010) untuk melihat aktivitas kelompok serbis di Kota Padang peneliti menggunakan teori sruktural fungsional. Asumsi dasar dari teori struktural fungsional menurut Parsons ini, adalah masyarakat terintegrasi atas dasar kesepakatan dari para anggota akan nilai-nilai kemasyarakatan yang mempunyai kemampuan mengatasi perbedaan-perbedaan sehingga masyarakat tersebut dipandang sebagai suatu sistem yang secara fungsional terintegrasi dalam suatu keseimbangan, dengan demikian masyarakat merupakan kumpulan sistem-sistem sosial yang terbentuk dari tindakan-tindakan sosial individu dan satu sama lain berhubungan dan saling ketergantungan. Pada dasarnya kelompok serbis di Kota Padang merupakan kumpulan wanita yang mempunyai latar belakang yang berbeda-beda, perbedaan lainnya juga terlihat pada status, usia, ekonomi, dll, untuk mengatasi perbedaan tersebut, mereka terintegrasi dengan kesamaan-kesamaan tertentu misalnya penampilan, hobi, keinginan. Hal inilah yang membuat mereka saling berhubungan dan mempunyai ketergantungan.

Kelompok sosial merupakan kumpulan individu yang hidup bersama yang saling berinteraksi dan mengalami hubungan timbal-balik antara anggota yang satu dengan anggota yang lain, yang terbentuk dari adanya tujuan yang sama, keyakinan yang sama akan perlunya pengelompokan, dan memiliki kepentingan yang sama serta adanya idiologi yang mengikat antara angota yang tergabung dalam sebuah kelompok (Soerjono, 1998).

\section{METODE PENELITIAN}

Penelitian ini merupakan penelitian kualitatif, dengan tipe penelitian studi kasus dan mengunakan analisis kualitatif berangkat dari pendekatan fenomenologisme yang sebenarnya lebih banyak anti terhadap pendekatan positivisme yang dianggap terlalu kaku, hitam putih, dan terlalu asa. Penelitian ini dilakukan di kota Padang, penelitian lebih banyak dilakukan di basecamp yang berada di Jalan Adinogoro Kelurahan Kayu Kalek Gang Mutiara Dalam No 23 Padang, di Simpang Damri Tabing (kedai Pak Eri), (kafe Delima) 
yang berada di Jalan Delima Agus Salim Padang. Alasan pemilihan lokasi penelitian ini adalah karena tempat tersebut dijadikan sebagai tempat untuk berkumpul oleh anggota kelompok serbis. Teknik pemilihan informan yang digunakan dalam penelitian ini adalah purposive sampling yaitu penarikan sampel secara sengaja yang bertujuan untuk mengumpulkan informasi penelitian sesuai dengan tujuan penelitian. Teknik pengumpulan data, wawancara, observasi dan dokumentasi. Teknik analisis data kualitatif reduksi data, Display Data atau Penyajian Data, Display Data atau Penyajian Data.

\section{HASIL DAN PEMBAHASAN}

Berdasarkan hasil observasi dan wawancara yang peneliti laksanakan pada bulan Maret 2016 ditemukan bahwa serbis adalah singkatan dari serba-bisa yang dibentuk atas kesepakatan bersama, yang diartikan sebagai cewek serba bisa. Kelompok serbis dibentuk dari kehidupan yang beranekaragam, hobi, bahkan adanya kesamaan karakter antara anggota dengan anggota lainnya, individu dengan individu lainnya, yang akhirnya membetuk kelompok sosial yakni kelompok sosial tomboy di kota Padang.

Anggota kelompok serbis terdiri dari sopir pribadi, pedagang, pengangguran dan bahkan ada yang berprofesi sebagai sopir angkot. Ciri-ciri anggota kelompok ini antara lain, para anggotanya memiliki tato pada tubuh para anggota, dilengan kanan, lengan kiri, punggung bahkan kaki mereka. Para anggota memiliki tato umum sesuai dengan gambar yang mereka inginkan serta tato khas kelompok mereka sebagai lambang persatuan yaitu rantai berduri. Rantai berduri yang kuat merupakan satu kesatuan yang utuh yang terhubung antara bagian satu dengan bagian yang lain, ini menggambarkan kebersamaan dan solidaritas antara anggota kelompok yang kuat antara anggota kelompok

Kelompok ini selalu berkumpul dengan para anggotanya disetiap malam Minggu di basecamp. Selain di basecamp anggota kelompok juga sering berkumpul di kafe atau di kedai tempat yang mereka senangi seperti persimpangan jalan. Ngumbar merupakan istilah dalam kelompok mereka yang artinya ngumpul bareng. Hasil pengamatan penulis ditemukan bahwa anggota kelompok terdiri dari 27 orang yang mempunyai latar belakang yang berbeda-beda diantaranya berasal dari keluarga kaya raya, menengah, keluarga Broken home, bahkan masyarakat biasa. Kelompok serbis menjadikan kontrakan, rumah/ sebagai basecamp mereka untuk berkumpul. 
Aaktivitas yang dilakukan oleh banyak ke hal-hal negatif, kelompok serbis ini bergaul dan bersosialisasi hanya sesama mereka dan kurang dapat menyesuaikan diri dengan masyarakat dimana mereka tinggal. Kelompok serbis ini menamai perkumpulan mereka sebagai sebuah komunitas, namun hahikatnya mereka lebih cocok dilihat sebagai kelompok sosial, dilihat dari jumlah anggota yang relative sedikit. Hasil wawancara dengan DN pada tanggal 16 Maret 2016 mengungkapkan "kegiatan yang dilaksanan biasanya setiap malam minggu berkumpul di base camp, sambil memainkan gitar, bernyayi dan melakukan kegiatan-kegiatan yang menyenangkan. Jika sudah mulai larut malam kelompok ini keluar dari basecamp, pergi ke club malam dan melakukan kegiatan disana bersama". Hasil Wawancara dengan BN menjelaskan hal yang sama dan jika anggota kelompok malas untuk berpergian maka melaksanakan aktivitas di basecamp. Anggota kelompok membeli minuman keras, dan clabbing di basecamp.

Hasil wawancara dengan ketua Rukun Tetangga (RT) menjelaskan bahwa kelompok serbis ini biasanya berkumpul di basecamp bergaul sesama perempuan saja tidak ada laki-laki. Kelompok ini diketui tidak melakukan kegiatan meresahkan masyarakat. Ketua RT tidak mengetahui bentuk konkrit kegiatan yang dilakukan kelompok tersebut. Berdasarkan hasil wawancara dengan kedua informan di atas dapat dimaknai bahwa kelompok serbis melakukan kegiatan dan berkumpul di basecamp setiap minggu, untuk menghilangkan kesusahan yang mereka rasakan.

Kelompok serbis merupakan suatu kelompok sosial yang ada dalam masyarakat yang terdiri dari perempuan berpenampilan tomboy. Secara fisik anggota kelompok serbis adalah perempuan, namun dilihat sekilas tampak mata mulai dari dandanan, gaya berpakaian, rambut, hobi sampai tingkah laku mirip laki-laki, bahkan mereka memiliki tato pada tubuh mereka. Dalam menganalisis penelitian ini, teori yang penulis gunakan adalah teori aksi (Action Theory) yang dikemukakan oleh Talcott Parsons. Teori aksi ini menyatakan bahwa individu melakukan suatu tindakan berdasarkan pengalaman, persepsi, pemahaman dan penafsiran pada suatu obyek atau situasi tertentu.

Tindakan individu itu merupakan tindakan sosial yang rasional, yaitu mencapai tujuan atas sasaran dengan sarana-sarana yang paling tepat. Jadi dapat disimpulkan bahwa asumsi dasar dari teori ini yaitu tindakan manusia muncul dari kesadarannya dan dari situasi lingkungan yang mengitarinya Dalam kelompok sosial serbis individu melakukan tindakan berdasarkan pengalaman, dan penafsiran suatu tindakan yang telah mereka lakukakan dalam kelompok sosial mereka di Kota Padang, penafsiran tersebut 
bahwa mereka menganggap tindakan dalam kelompok sosial mereka adalah suatu bentuk pilihan mereka, dan pilihan tersebut merupakan ketengan bagi mereka, dengan adanya suatu kelompok sosial mereka bisa mengekspresikan diri mereka, dan mereka menganggap adanya kebersamaan dari perkumpulan yang dilakukan dalam kelompok sosial, dan tindakan individu dalam kelompok sosial merupakan tindakan yang rasional yaitu mencapai tujuan atas sarana, dan sarana tersebut adalah kelompok sosial serta tindakan manusia muncul dari kesadaran dan dari situasi lingkungan yang mengintarinya.

\section{E. Simpulan}

Hasil penelitian mengambarkan bahwa aktivitas kelompok serbis ini adalah berkumpul bersama di basecamp dan melaksanakan kegiatan bersenang-senang seperti: bernyayi, bersama, bergitar bersama dan pergi ke cafe-cafe untuk clabbing. Aktivitas yang mereka laksanakan kebanyakan hanya untuk mengatasi perasaan sedih dan susah karena kebanyakan berasal dari keluarga yang broken home. Keinginan dan inspirasinya tidak dapat terpenuhi di rumah makanya para perempuan tomboy ini melaksanakan kegiatan di luar rumah dan bergabung dengan kelompok serbis.

Temuan dari penelitian ini menjadi informasi penting bagi para orang tua agar meningkatkan kewaspadaan terhadap pergaulan anak khususnya perempuan. Kondisi hubungan rumah tangga yang kurang harmonis antara suami dan istri, juga perlu dicarikan solusi oleh orang tua karena dapat menjadi perusak kepribadian anak. 


\section{DAFTAR REFERENSI}

Abdulsyani. Sosiologi Skematika, Teori, dan Terapan. Jakarta: Bumi Aksara. 2007

Dailymail. Psikologi Remaja Edisi I Jakarta :PT Raja Grafindo Persada. 2007.

J.Dwi Narwoko dan Bagong Suyanto. Sosiologi Teks Pengantar dan Terapan. Jakarta: Kencana. 2007.

K. J. Veerger. Jakarta. Realitas Sosial, Refleksi Filsafat Scsial atas Hubungan Individu-Masyarakat dalam Cakrawala Sejarah Sosiologi.. Gramedia Pustaka Utama. 1990.

Ritzer\& Goodman. Teori Sosiologi Modern, Edisi ke 6. Jakarta: Kencana. 2010.

Soekanto Soerjono. Sosiologi Suatu Pengantar:PT Raja Grafindo. 1988.

Susanti. Psikologis Cewek Tombaoy di Kota Padang. Skripsi Fisip Unand. 2005.

Syafriati Putri. Perspektif Cewek Tomboy Dalam Kebidupan Masyarakat. Skripsi FISIP Unand. 2003.

Wawancara dengan Fitrinella (Anggota Kelompok serbis) Pada Tanggal 9 maret 2013 